\title{
Antioxidant and Antibacterial Potencies of Xanthoparmelia conspersa (Ehrh. ex Ach.) Hale and Dermatocarpon miniatum (L.) W. Mann. Lichens from Black Sea Region in Turkey
}

\author{
Türkiye'de Karadeniz Bölgesi'ndeki Xanthoparmelia conspersa (Ehrh. ex Ach.) Hale and \\ Dermatocarpon miniatum (L.) W. Mann. Likenlerinin Antioksidan ve Antibakteriyal \\ Potansiyelleri
}

Zeynep KARAAHMET ${ }^{\mathrm{a}}$, Kadir KINALIOĞLU ${ }^{\mathrm{b}}$, Sinem AYDIN*c

Giresun University, Faculty of Science and Arts, Department of Biology, Giresun University, 28100, Giresun

\author{
• Geliş tarihi / Received: 20.10.2018 • • Düzeltilerek geliş tarihi / Received in revised form: 04.01.2019 • Kabul tarihi / Accepted: 05.02.2019
}

\begin{abstract}
Antibacterial properties of Dermatocarpon miniatum (L.) W. Mann and Xanthoparmelia conspersa (Ehrh. ex Ach.) Hale lichens were investigated by disc diffusion and Minimum Inhibitory Concentration (MIC) methods. Antioxidant capacity of the lichens were examined by utilizing 2,2-diphenyl-1picrylhydrazyl (DPPH) radical scavenging activity, 2,2'Azino-bis (3-ethylbenzenotiazoline-6-sulphonic acid (ABTS) radical scavenging activity, metal chelating activity, total antioxidant capacity, determination of total phenolic and total flavonoid contents. Extracts showed antibacterial effect against all bacteria except for Escherichia coli and Salmonella enterica. When compared antibacterial efficiency of the tested lichens, it is concluded that $X$. conspersa lichen is more active than $D$. miniatum lichen. DPPH radical scavenging activity of the extracts are increased in the following order: ethanol extract of $X$. conspersa $>$ acetone extract of $D$. miniatum > ethanol extract of $D$. miniatum $>$ acetone extract of $X$. conspersa. Studied lichen extracts showed relatively weak metal chelating activity. According to the obtained results, it is concluded that $D$. miniatum and $X$. conspersa lichen extracts can be alternative antibacterial and antioxidant agents.
\end{abstract}

Keywords: Antibacterial Activity, Antibiotic, Antioxidant Activity, Lichen

\section{$\ddot{O} z$}

Dermatocarpon miniatum (L.) W. Mann ve Xanthoparmelia conspersa (Ehrh. Ex. Ach.) Hale likenlerinin antibakteriyel özellikleri disk difüzyon ve Minimum Inhibitör Konsantrasyon (MIK) yöntemleri ile araştırıld. Likenlerin antioksidan kapasitesi, 2,2-difenil-1-pikrilhidrazil (DPPH) radikal temizleme aktivitesi, 2,2'Azino-bis (3-etilbenzenotiazolin-6sülfonik asit (ABTS) radikali temizleme aktivitesi ve metal şelatlama aktivitesi kullanılarak incelenmiştir. Toplam antioksidan kapasite toplam fenolik ve toplam flavonoid içeriğinin belirlenmesi yöntemleri kullanılarak araştırıldl. Ekstraktlar Escherichia coli ve Salmonella enterica dişındaki diğer tüm bakterilere karşı antibakteriyel etki göstermiştir. Test edilen likenlerin antibakteriyel etkinliği karşılaştırıldı̆̆ında, X. conspersa likeninin D. miniatum likeninden daha aktif olduğu belirlenmiştir. D. miniatum liken ekstraktların DPPH radikal temizleme aktiviteleri X. conspersa'nın etanol ekstraktı > D. miniatum'un aseton ekstraktı $>D$. miniatum'un etanol ekstraktı $>X$. conspersa'nın aseton ekstraktı şeklinde sıralanmıştır. Çalışılan liken ekstraktları oldukça zaylf metal şelatlama aktivitesi göstermiştir. Çalışmadan elde edilen sonuçlar D. miniatum ve X. conspersa liken ekstraktlarının antibakteriyel ve antioksidan ajanlara alternatif olarak kullanilabileceklerini göstermektedir.

Anahtar kelimeler: Antibiyotik, Antibakteriyal Aktivite, Antioksidan Aktivite, Liken

\footnotetext{
*c Sinem AYDIN; sinem.aydin@ giresun.edu.tr; Tel: (0454) 31040 11; orcid.org/ 0000-0002-0484-7191

${ }^{\mathrm{a}}$ orcid.org/0000-0002-0842-4241 $\quad{ }^{\mathrm{b}}$ orcid.org/0000-0001-6564-7778
} 


\section{Introduction}

The outbreak of resistance to pathogenic bacteria to the current antibacterial agents is a very general and threatening trouble around the world. Besides intrinsic ability of bacteria, extrinsic factors cause acquiring resistance of bacteria to antibiotics. These extrinsic factors are using improper and extensive antibiotics and deficiency of appropriate or late diagnosis of infection. Consequently, there is a perpetual demand for brand and effective antibacterial drugs (Rani et al., 2017).

Medicinal plants have been utilized in the treatment of many infectious diseases. Medicinal plants are natural alternatives to antimicrobial agents (Mahesh and Satish, 2008). Antibiotics are occasionally have side effects but using medicinal plants have some benefits like little side effects, relatively cheap and better patient tolerance (Joshi and Sahu, 2014).

Nowadays, there has been a rising demand in utilizing of traditional plants for curative antioxidant agents. An antioxidant can be described as any substance that retards, hinders or eliminates oxidative detriment to a target molecule. Natural antioxidants are known to demonstrate a great deal of biological impacts such as antibacterial, anti-inflammatory, antiviral, antiallergic and anticancer efficiency (Aadesariya et al., 2017).

Recently, most of the antioxidants are producted synthetically. Butylated hydroxyl anisole (BHA), Butylated hydroxyl toluene (BHT) and gallic acid which are synthetic antioxidants are known to possess possible side influence carcinogenicity. Because of this situation, using synthetic antioxidants are restricted. Antioxidant substances derived from plants are reliable and complete the effect of free radicals thus preserving the organism from many different kind of diseases. For this reason, an interest to investigate medicinal plants for the existence of natural antioxidants has rised (Reddey and Grace, 2016).

Lichens are the symbiotic associations including a fungal partner and an algal partner and they are recognize to possess medicinal effects on many illnesses in folk medicine in worldwide (Sharma and Kalikotay, 2012).

Antibacterial and antioxidant properties of lichen species have been recognized for long years. These activities of lichens has been recorded by several researchers (Rankovic et al., 2010; Buçukoğlu et al., 2013; Sisodia et al., 2013).

Antibacterial and antioxidant activities of acetone and methanol extracts of Usnea rubratincta, Ramalina dumeticola and Cladonia verticillata were investigated and it was found that some extracts inhibited Staphylococcus aureus and Bacillus subtilis. Moreover, it was found that DPPH activity of the extracts ranged from $16.4 \%$ and $33.09 \%$ (Gunasekaran et al., 2016).

Paudel et al. (2012) searched antioxidant and antibacterial activities of twenty four lichen species. It was found that extracts of twenty one lichen species were active against Bacillus subtilis and seven species were active against Staphylococcus aureus. Besides, in DPPH assay, Peltigera sp., Cladonia sp., and Canoparmelia sp. exhibited comparable activity with standard antioxidant BHA. However in ABTS assay, extracts of Parmoterma sp., Ramalina sp., Peltigera sp. and Cladonia sp. showed stronger activity than standard antioxidant ascorbic acid.

Antioxidant and antimicrobial activities of chloroform, methanol and water extracts of Cladonia rangiformis Hoffm. were also screened. Extracts exhibited weak antibacterial activity but no antifungal activity against test microrganisms (Yücel et al., 2007).

Dermatocarpon miniatum (L.) W. Mann traditionally used in China to reduce high blood pressure, diuretic, inadequate nutrition in children, dysentery, regulation of digestion and elimination of abdominal distension (Crawford, 2015).

The other lichen species that makes up our work is the Xanthoparmelia conspersa (Ehrh. ex Ach.) Hale. It is utilized in the treatment of snake bites, cuts, treatment of inflammatory gingivitis, and treatment of sore throat (Crawford, 2015).

In this study, we targeted to search antibacterial and antioxidant activities of $X$. conspers $a$ and $D$. miniatum lichens.

\section{Material and Methods}

\subsection{Lichen Materials}

D. miniatum and $X$. conspersa specimens used in the study were collected from the following localities which located in Giresun in 2016 (Table $1)$. 
These specimens were dried at room temperature and identified using Smith et al. (2009). A voucher specimens of the lichens (D. miniatum: Herb. no: 6396, X. conspersa Herb. no: 6397) were kept in the Biology Department, Faculty of Science and Arts, Giresun University, Giresun, Turkey.

Table 1. Localities where lichens are collected

\begin{tabular}{|c|c|}
\hline D. miniatum & $\begin{array}{l}\text { Giresun, E of Giresun Castle, } 110 \mathrm{~m} \text {, } \\
40^{\circ} 55^{\prime} 13^{\prime \prime} \mathrm{N}, 38^{\circ} 23^{\prime} 25 \mathrm{E} ", \\
12.03 .2006 .\end{array}$ \\
\hline$X . c$ & $\begin{array}{l}\text { Giresun, Keşap, Değirmenağzı } \\
\text { village, sea shore, } 2 \mathrm{~m}, 40^{\circ} 58^{\prime} 23^{\prime \prime} \mathrm{N} \text {, } \\
38^{\circ} 37^{\prime} 29 \mathrm{E}^{\prime \prime}, 19.06 .2015 .\end{array}$ \\
\hline
\end{tabular}

\subsection{Test Microorganisms}

Six gram negative and five gram positive bacteria were utilized in the current study.

\subsection{Extract Preparation}

$15 \mathrm{~g}$ of the powdered sample were extracted with Soxhlet apparatus utilizing $150 \mathrm{~mL}$ acetone and ethanol solvents, separetely. The extraction process followed by filtration with Whatman filter paper no 1 . The filtered extract concentrated in vacuo at $40^{\circ} \mathrm{C}$ using a rotary evaporator. Extracts were kept at $-80^{\circ} \mathrm{C}$ for other tests (Kumar et al., 2012).

Table 2. Bacteria which used in the study.

\begin{tabular}{lll}
\hline Bacteria & $\begin{array}{l}\text { Gram (+) Bacteria / } \\
\text { Gram (-) Bacteria }\end{array}$ & Where obtained from \\
\hline Salmonella enterica ATCC 14028 & Gram (-) & Giresun Province Control Laboratory \\
Proteus vulgaris FMC 1 & Gram (-) & Firat University \\
Enterobacter aerogenes CCM 2531 & Gram (-) & Frrat University \\
Yersinia pseudotuberculosis ATCC 911 & Gram (-) & Rize University \\
Escherichia coli ATCC 35218 & Gram (-) & Giresun University \\
Klebsiella pneumoniae (laboratory isolate) & Gram (-) & Yeditepe University \\
Gordonia rubripertincta (lab isolate) & Gram (+) & Yeditepe University \\
Bacillus megaterium (laboratory isolate) & Gram (+) & Yeditepe University \\
Staphylococcus aureus subsp. aureus ATCC 25923 & Gram (+) & Giresun Province Control Laboratory \\
Bacillus cereus 702 ROMA & Gram (+) & Firat University \\
Bacillus cereus 702 ROMA & Gram (+) & Rize University \\
\hline
\end{tabular}

\subsection{Antibacterial Activity of the Lichens}

On Mueller-Hinton agar each bacterial inoculum was swab streaked that has been formerly arranged by inoculating bacterial strains into nutrient broth with overnight incubation. Crude extracts were dissolved with DMSO at $15 \mathrm{mg} / \mathrm{mL}$. Then, they were sterilized by using $0.45 \mu \mathrm{m}$ pore sized filter. The discs were put into agar plates and filled with $25 \mu \mathrm{L}$ ethanol extract of $D$. miniatum, $25 \mu \mathrm{L}$ acetone extract of $D$. miniatum, $25 \mu \mathrm{L}$ ethanol extract of $X$. conspersa, $25 \mu \mathrm{L}$ acetone extract of $X$. conspersa and $25 \mu \mathrm{L}$ DMSO. Tetracycline and gentamycine discs were utilized as standard antibacterial agents. Plates were then incubated for $24 \mathrm{~h}$ at $37{ }^{\circ} \mathrm{C}$. The clear zone of inhibition was observed and measured in $\mathrm{mm}$ (Murray et al., 1995; Šarić et al., 2009).

\subsection{Determination of MIC}

The MIC was defined by the broth tube dilution method (NCCLS, 1993). A series of dilutions with concentrations ranging from 15 to 0.02929 $\mathrm{mg} / \mathrm{mL}$ for extracts was utilized in the assay against each microorganism tested. Extracts dissolved in DMSO. Two-fold dilutions of extracts were prepared in Mueller-Hinton broth in test tubes (Marijana et al., 2010).

\subsection{Antioxidant Capacity of $X$. conspersa and $D$. miniatum}

\subsubsection{Total Phenolic Content}

Total phenolic content of lichen extracts was determined by the procedure of Slinkard and Singleton (1977) using gallic acid standard. The absorbance was measured at $760 \mathrm{~nm}$. The quantity of the total phenolic compounds was denoted as $\mu \mathrm{g}$ gallic acid equivalent (GAE) $/ \mathrm{mL}$. The tests were carried out three times The tests were carried out three times.

\subsubsection{Total Flavonoid Content}

Total flavonoid content of lichen extracts was determined by the method of Zhishen et al. (1999). Absorbance was read spectrometrically at $510 \mathrm{~nm}$. The amount of total flavonoid compounds was calculated as $\mu \mathrm{g}$ catechin 
equivalent $(\mathrm{CE}) / \mathrm{mL}$. The tests were carried out three times.

\subsubsection{Metal Chelating Activity}

Lichen extracts and standard (EDTA) were prepared at concentrations of $250-1000 \mu \mathrm{g} / \mathrm{mL}$. The absorbance was measured at $562 \mathrm{~nm}$ (Loizzo et al., 2012). Results are calculated from the following equation:

$\%$ Activity: $\left[\frac{A 0-A 1}{A 0}\right] X 100$

$\mathrm{A} 0=\mathrm{Absorbance}$ of control

$\mathrm{A} 1=$ Absorbance of sample

\subsubsection{ABTS Radical Scavenging Activity}

ABTS radical scavenging activity of lichen samples were made according to the method developed by Arnao et al. (2001). The absorbance was measured at $734 \mathrm{~nm}$. BHT and rutin used as standards. The tests were carried out three times. The results are calculated from the following equation:

$\%$ Activity: $\left[\frac{A 0-A 1}{A 0}\right] X 100$

$\mathrm{A}_{0}=$ Absorbance of control

$\mathrm{A}_{1}=$ Absorbance of sample

\subsubsection{Total Antioxidant Capacity}

Total antioxidant capacity of the extracts was defined according to Prieto et al., (1999). Absorbance was measured at $695 \mathrm{~nm}$. The results were calculated as $\mu \mathrm{g}$ ascorbic acid equivalent (AAE) $/ \mathrm{mL}$ lichen sample from ascorbic acid standard graphical equation. The tests were carried out three times.

\subsubsection{DPPH Radical Scavenging Activity}

The free radical scavenging activity of ethanol and acetone solvent extracts of D. miniatum and $X$. conspersa were measured by utilizing the method of Brand-Williams et al. (1995). Lichen extracts were prepared at 250-1000 $\mu \mathrm{g} / \mathrm{mL}$ concentrations. The percentage inhibition was established by comparing the results of the test and the control. The tests were carried out three times. Percentage of activity was calculated using the following formula:

$\%$ Activity: $\left[\frac{A 0-A 1}{A 0}\right] X 100$

$\mathrm{A}_{0}=$ Absorbance of control

$\mathrm{A}_{1}=$ Absorbance of sample

\section{Results and Discussion}

\subsection{Antibacterial Activity}

The existence of biologically active compounds in lichens is studied in worldwide (Molnar and Farkas, 2010). The utilization of lichens in medicinally is based on their unique and biologically active substances, such as antimicrobial actions (Manojlovic et al., 2002; Saenz et al., 2006).

Results acquired in the present study demonstrated that the studied lichen extracts have possible antibacterial effect against all the test bacteria except for $S$. enterica and $E$. coli. Acetone extracts showed higher activity when compared to ethanol extracts (Table 3).

Table 3. Inhibition zones of the lichen extracts (mm)

\begin{tabular}{|c|c|c|c|c|c|c|c|}
\hline Microorganisms & EED & AED & EEX & AEX & Tetra & Genta & DMSO \\
\hline E. coli & NA & NA & NA & NA & 18 & 17 & NA \\
\hline Y. pseudotuberculosis & NA & 8 & 8 & 6 & NA & 18 & NA \\
\hline B. cereus & 7 & 16 & 9 & 18 & 18 & 21 & NA \\
\hline S. enterica & NA & NA & NA & NA & 17 & 18 & NA \\
\hline B. subtilis & 12 & 11 & 12 & 18 & 12 & 18 & NA \\
\hline P. vulgaris & 8 & 12 & 10 & 16 & 10 & 16 & NA \\
\hline B. megaterium & NA & 7 & 14 & NA & 20 & 15 & NA \\
\hline S. aureus subsp. aureus & NA & 6 & 9 & 11 & 22 & 14 & NA \\
\hline K. pneumoniae & NA & NA & 8 & 6 & 15 & 19 & NA \\
\hline G. rubripertincta & NA & NA & 10 & 15 & 17 & 14 & NA \\
\hline E. aerogenes & 6 & 9 & 10 & 15 & NA & 20 & NA \\
\hline
\end{tabular}

EED: Ethanol extract of D. miniatum; AED: Acetone extract of D. miniatum; EEX: Ethanol extract of X. conspersa; AEX: Acetone extract of $X$. conspersa; NA: No Activity; Tetra: Tetracycline10 $\mu \mathrm{g} / \mathrm{disc}$; Genta: Gentamycine $10 \mu \mathrm{g} / \mathrm{disc}$ 
The highest antibacterial activity obtained against B. subtilis $(18 \mathrm{~mm})$ and $B$ cereus $(18 \mathrm{~mm})$ and the lowest activity was found against E. aerogenes (6 $\mathrm{mm})$, S. aureus $(6 \mathrm{~mm})$, K. pneumoniae $(6 \mathrm{~mm})$ and $Y$. pseudotuberculosis $(6 \mathrm{~mm})$. DMSO which was used as negative control exhibit no activity against bacteria. Tetracycline demonstrated higher effect than the lichen extracts. When antibacterial activity of the extracts was compared, it was found that $X$. conspersa extracts was more active than D. miniatum.

The antibacterial efficiency of the extracts of $X$. conspersa and D. miniatum are seen in Table 4. The results revealed that the lichen extracts exhibited antibacterial activities at variable degrees against test bacteria, with MIC values varying from 3.75 to $0.02929 \mathrm{mg} / \mathrm{mL}$. The extracts of $X$. conspersa have lower MIC values than D. miniatum.

There are very limited studies about antimicrobial activity of D. miniatum. For example, Aslan et al. (2006) determined that methanol extract of $D$. miniatum weak antimicrobial activity. The extract showed no antifungal activity but the extract was active against $B$. subtilis and Clavibacter michiganensis. In aggrement with this study we also found activity against $B$. subtilis. On the other hand, there are studies about antimicrobial activity of different Dermatocarpon species. Balasubramanian and Nirmala (2014a) evaluated antimycobacterial activity of ethyl acetate, acetone, chloroform, diethyl ether, methanol, ethanol and hexane extracts of Dermatocarpon vellereum Zschacke. Sharma et al. (2012) searched methanol and acetone extracts of Dermatocarpon spp. against five pathogenic clinical isolates of E. coli, and $S$. aureus. Results of these studies and our study are different because of collecting lichens different localities and using different Dermatocarpon species.

$X$. conspersa lichen was also studied by other researchers. For example, Duman (2009) investigated acetone extract of $X$. conspersa against Escherichia coli, Enterococcus faecalis, Proteus mirabilis, Staphylococcus aureus, Bacillus subtilis, Bacillus megaterium and $P$ seudomonas aeruginosa. Acetone extract of $X$. conspersa lichen was active against all the tested bacteria except for $S$. aureus and $P$. aeruginosa. $X$. conspersa lichen was effective against Colletotrichum acutatum, C. coccodes and $C$. gloeosporioides which cause anthracnose in red pepper (Jeon et al., 2009). Laska and Kiercul (2014) studied pharmacologic activity (antibacterial, antiviral and anticancer) of metabolites isolated from $X$. conspersa lichen. Acetone extract of $X$. conspersa lichen inhibited biofilm formation of Candida albicans (Millot et al., 2017). It was also reported that stictic acid which was obtained from $X$. conspersa lichen has antioxidant activity (De Paz et al., 2010). Studies of mentioned above and our study are different because of using different solvent.

Table 4. MIC values of the lichen extracts $(\mathrm{mg} / \mathrm{mL})$

\begin{tabular}{lllll}
\hline Bacteria & EED & AED & EEX & AEX \\
\hline E. coli & NA & NA & NA & NA \\
Y. pseudotuberculosis & NA & 3.75 & 3.75 & 3.75 \\
B. cereus & 3.75 & 0.234375 & 0.46875 & 0.05859 \\
S. enterica & NA & NA & NA & NA \\
B. subtilis & 3.75 & 0.1171875 & 0.1171875 & 0.05859 \\
P. vulgaris & 3.75 & 0.1171875 & 0.05859 & 0.02929 \\
B. megaterium & NA & 1.875 & 0.46875 & NA \\
E. aerogenes & 15 & 3.75 & 1.875 & 0.1171875 \\
S. aureus subsp. aureus & NA & 3.75 & 0.46875 & 0.1171875 \\
K. pneumoniae & NA & - & 3.75 & 1.875 \\
G. rubripertincta & NA & NA & 0.46875 & 0.234375 \\
\hline
\end{tabular}

NA: No Activity

\subsection{Antioxidant Activity}

Ethanol and acetone extracts of $X$. conspers $a$ and $D$. miniatum collected from Black Sea Region were screened with regard to their contents of total phenols. Table 5 is seen the total phenol contents that were determined by Folin Ciocalteu reagent in terms of gallic acid equivalent (GAE). Total phenolic content of the extracts are ranged from $25.08 \pm 0.002$ to $209.92 \pm 0.01 \mu \mathrm{g} \mathrm{GAE} / \mathrm{mL}$ lichen extract. The highest and the lowest phenolic content were measured in acetone extract of $X$. conspersa and acetone extract of $D$. miniatum, separetely. Phenolic compounds have 
been declared to be linked with antioxidative effect in biological systems, acting as scavengers of singlet oxygene and free radicals (El Hajaji et al., 2010).

Flavonoids are one class of secondary plant metabolites that are recognise as Vitamin P. They are commonly utilized in plants to generate yellow and other coloured pigments which have a crucial role in the colors of plants. Moreover, flavonoids exhibit significant anti-cancer, antiinflammatory and anti-allergic activities (Rebeya et al., 2014).

The amount of total flavonoid content is expressed as $\mu \mathrm{g} \mathrm{CE} / \mathrm{mL}$ lichen extract. Total flavonoid content of the lichens was given in Table 5. Acetone extract of $X$. conspersa exhibited maximum and ethanol extract of $D$. miniatum showed minimum flavonoid content. $X$. conspersa lichen possesses higher total flavonoid activity than $D$. miniatum lichen.

The phosphomolybdenum procedure is primarily based on the reduction of molybdenum, Mo (VI) to Mo (V) by the effect of antioxidant substances and the generation of a green phosphate, Mo (V) complex with a highest absorption at $695 \mathrm{~nm}$ (Hossain et al., 2017). Total antioxidant capacities of the extracts are given in Table 5. Total antioxidant capacity of the extracts increased in the following order: Ethanol extract of $D$. miniatum > acetone extract of $X$. conspersa > ethanol extract of $X$. conspersa $>$ acetone extract of $D$. miniatum.

Table 5. Total phenolic and flavonoid contents and total antioxidant capacity of the tested lichen extracts

\begin{tabular}{|c|c|c|c|}
\hline Lichen & $\begin{array}{l}\text { Total phenolic content } \\
\text { ( } \mu \text { g GAE/mL lichen } \\
\text { extract) }\end{array}$ & $\begin{array}{l}\text { Total flavonoid content } \\
\text { ( } \mu \text { g CE/mL lichen } \\
\text { extract) }\end{array}$ & $\begin{array}{l}\text { Total antioxidant } \\
\text { capacity }(\mu \mathrm{g} \text { AAE } / \mathrm{mL} \\
\text { lichen extract) }\end{array}$ \\
\hline $\begin{array}{l}\text { Ethanol extract of } D . \\
\text { miniatum }\end{array}$ & $86.27 \pm 0.007$ & $44.79 \pm 0.006$ & $92.59 \pm 0.02$ \\
\hline $\begin{array}{l}\text { Acetone extract of } D \text {. } \\
\text { miniatum }\end{array}$ & $25.08 \pm 0.002$ & $52.20 \pm 0.01$ & $48.43 \pm 0.07$ \\
\hline $\begin{array}{l}\text { Ethanol extract of } X \text {. } \\
\text { conspersa }\end{array}$ & $67.72 \pm 0.01$ & $68.68 \pm 0.03$ & $52.58 \pm 0.05$ \\
\hline $\begin{array}{l}\text { Acetone extract of } X \text {. } \\
\text { conspersa }\end{array}$ & $209.92 \pm 0.01$ & $83.60 \pm 0.02$ & $63.54 \pm 0.006$ \\
\hline
\end{tabular}

Values are expressed as means of three replicates \pm SD

DPPH radical scavenging activity of the extracts was indicated in Table 6. DPPH radical quenching activity of the studied lichen extracts increase as ethanol extract of $X$. conspersa $>$ acetone extract of $D$. miniatum > ethanol extract of $D$. miniatum $>$ acetone extract of $X$. conspersa. In addition, DPPH radical scavenging activity of extracts is a dose-dependent manner.

ABTS radical scavenging activities of the extracts are given in Table 6 . The highest activity was detected in ethanol extract of $X$. conspersa. ABTS radical scavenging activity of extracts is a dosedependent manner.

ABTS and DPPH radicals scavenging activities of the extracts and standards also are expressed as half maximal inhibitory concentrations $\left(\mathrm{SC}_{50}\right)$ values, calculated from the regression equations prepared from the concentrations of samples. A higher scavenging activity is associated with a lower $\mathrm{SC}_{50}$ value.

Chelating agents can inhibit radical formations by stabilizing transition metals consequently reducing free radical injury. Moreover, some phenolic compounds demonstrate antioxidant action through the chelating of metal ions (Yumrutas and Saygideger, 2012). Metal chelating actvity of the lichens is shown in Table 6. Only extracts of $X$. conspersa exhibited too weak metal chelating activity. EDTA which is standard antioxidant showed very high activity when compared with the extracts.

There are some studies about antioxidant activity of Dermatocarpon and $X$. conspersa lichen species. For examle, Aslan et al., (2006) was stated that $\mathrm{IC}_{50}$ values of the methanol extract of D. miniatum was found as $396.1 \mu \mathrm{g} / \mathrm{mL}$ and total phenolic content was $2.9 \%$. 
Table 6. DPPH and ABTS radical scavenging activities and metal chelating activity of the tested lichen extracts

\begin{tabular}{|c|c|c|c|c|c|c|}
\hline Lichen & $\begin{array}{l}\text { Concentration } \\
(\mu \mathrm{g} / \mathrm{mL})\end{array}$ & $\begin{array}{l}\text { DPPH radical } \\
\text { scavenging } \\
\text { activity }(\% \\
\text { activity) }\end{array}$ & $\begin{array}{l}\mathrm{SC}_{50} \text { values for } \\
\text { DPPH radical } \\
\text { scavenging } \\
\text { activity }\end{array}$ & $\begin{array}{l}\text { Metal chelating } \\
\text { activity (\% } \\
\text { activity) }\end{array}$ & $\begin{array}{l}\text { ABTS radical } \\
\text { scavenging } \\
\text { activity (\% } \\
\text { activity) }\end{array}$ & $\begin{array}{l}\mathrm{SC}_{50} \text { values for } \\
\text { ABTS radical } \\
\text { scavenging } \\
\text { activity }\end{array}$ \\
\hline $\begin{array}{l}\text { Ethanol } \\
\text { extract of } D . \\
\text { miniatum }\end{array}$ & $\begin{array}{l}250 \\
500 \\
750 \\
1000\end{array}$ & $\begin{array}{l}6.87 \pm 0.01 \\
22.72 \pm 0.03 \\
34.17 \pm 0.04 \\
41.63 \pm 0.03\end{array}$ & $939.34 \pm 8.73$ & $\begin{array}{l}\text { NA } \\
\text { NA } \\
\text { NA } \\
\text { NA }\end{array}$ & $\begin{array}{l}21.14 \pm 0.05 \\
59.21 \pm 0.008 \\
77.20 \pm 0.010 \\
83.87 \pm 0.02\end{array}$ & $531.33 \pm 14.24$ \\
\hline $\begin{array}{l}\text { Acetone } \\
\text { extract of } D . \\
\text { miniatum }\end{array}$ & $\begin{array}{l}250 \\
500 \\
750 \\
1000\end{array}$ & $\begin{array}{l}10.43 \pm 0.02 \\
16.49 \pm 0.02 \\
35.20 \pm 0.02 \\
49.03 \pm 0.01\end{array}$ & $1072.66 \pm 26.03$ & $\begin{array}{l}\text { NA } \\
\text { NA } \\
\text { NA } \\
\text { NA }\end{array}$ & $\begin{array}{l}8.73 \pm 0.03 \\
38.36 \pm 0.04 \\
63.41 \pm 0.02 \\
81.12 \pm 0.02\end{array}$ & $633.87 \pm 0.64$ \\
\hline $\begin{array}{l}\text { Ethanol } \\
\text { extract of } X . \\
\text { conspersa }\end{array}$ & $\begin{array}{l}250 \\
500 \\
750 \\
1000\end{array}$ & $\begin{array}{l}44.34 \pm 0.01 \\
50.22 \pm 0.06 \\
57.92 \pm 0.02 \\
64.92 \pm 0.005\end{array}$ & $614.68 \pm 1.95$ & $\begin{array}{l}0.345 \pm 0.005 \\
0.522 \pm 0.02 \\
1.27 \pm 0.01 \\
4.11 \pm 0.02\end{array}$ & $\begin{array}{l}85.48 \pm 0.03 \\
93.39 \pm 0.002 \\
94.07 \pm 0.006 \\
96.84 \pm 0.007\end{array}$ & $209.00 \pm 5.55$ \\
\hline $\begin{array}{l}\text { Acetone } \\
\text { extract of } X . \\
\text { conspersa }\end{array}$ & $\begin{array}{l}250 \\
500 \\
750 \\
1000\end{array}$ & $\begin{array}{l}18.84 \pm 0.01 \\
24.61 \pm 0.03 \\
29.20 \pm 0.03 \\
32.25 \pm 0.01\end{array}$ & $1350 \pm 34.32$ & $\begin{array}{l}\text { NA } \\
\text { NA } \\
\text { NA } \\
5.71 \pm 0.02\end{array}$ & $\begin{array}{l}\text { NA } \\
\text { NA } \\
\text { NA } \\
24.36 \pm 0.007\end{array}$ & NA \\
\hline BHT & $\begin{array}{l}250 \\
500 \\
750 \\
1000\end{array}$ & $\begin{array}{l}88.85 \pm 0.01 \\
89.55 \pm 0.005 \\
90.27 \pm 0.01 \\
91.55 \pm 0.008\end{array}$ & $204.25 \pm 2.62$ & $\begin{array}{l}\text { NS } \\
\text { NS } \\
\text { NS } \\
\text { NS }\end{array}$ & $\begin{array}{l}93.48 \pm 0.01 \\
93.92 \pm 0.006 \\
94.43 \pm 0.004 \\
96.65 \pm 0.008\end{array}$ & $170.1 \pm 0.80$ \\
\hline Rutin & $\begin{array}{l}250 \\
500 \\
750 \\
1000\end{array}$ & $\begin{array}{l}86.80 \pm 0.008 \\
87.91 \pm 0.003 \\
90.60 \pm 0.004 \\
91.89 \pm 0.01\end{array}$ & $209.13 \pm 5.77$ & $\begin{array}{l}\text { NS } \\
\text { NS } \\
\text { NS } \\
\text { NS }\end{array}$ & $\begin{array}{l}78.54 \pm 0.04 \\
81.94 \pm 0.01 \\
85.26 \pm 0.01 \\
87.63 \pm 0.006\end{array}$ & $272 \pm 8.93$ \\
\hline EDTA & $\begin{array}{l}250 \\
500 \\
750 \\
1000\end{array}$ & $\begin{array}{l}\text { NS } \\
\text { NS } \\
\text { NS } \\
\text { NS }\end{array}$ & $\begin{array}{l}\text { NS } \\
\text { NS } \\
\text { NS } \\
\text { NS }\end{array}$ & $\begin{array}{l}94.27 \pm 0.03 \\
97.53 \pm 0.01 \\
99.89 \pm 0.0004 \\
99.91 \pm 0.0004\end{array}$ & $\begin{array}{l}\text { NS } \\
\text { NS } \\
\text { NS } \\
\text { NS }\end{array}$ & $\begin{array}{l}\text { NS } \\
\text { NS } \\
\text { NS } \\
\text { NS }\end{array}$ \\
\hline
\end{tabular}

NA: No Activity; NS: No Studied. Values are expressed as means of three replicates \pm SD

On the other hand, we found total phenolic contents of ethanol and acetone extracts of $D$. miniatum as $86.27 \pm 0.007 \mu \mathrm{g} \quad \mathrm{GAE} / \mathrm{mL}$ and $25.08 \pm 0.002 \mu \mathrm{g} \mathrm{GAE} / \mathrm{mL}$, respectively in the study. Total antioxidant activity, total phenolic content and reducing power of methanol and water extracts of Dermatocarpon intestiniformis was also screened (Odabasoglu et al., 2005). Balasubramanian and Nirmala (2014b) investigated antioxidant properties of Dermatocarpon vellereum lichen.

Kumar et al. (2014) explained that methanol extract of $X$. conspersa exhibited high antioxidant activity. Similarly, Sökmen et al. (2018) found high CUPRAC activity in acetonitrile extracts of $X$. stenophylla lichen. We also found antioxidant activity in $X$. conspersa extracts at varying degrees.

\section{Conclusion}

The results of the current research proposed that $D$. miniatum and $X$. conspersa lichens might be a possible natural alternative of synthetic antioxidants and might have gained significance as healing agent in hindering or decelerating oxidative stress linked with degenerative diseases. Furthermore, these lichens might be utilized to produce brand, different and more effective antimicrobial medicines of natural origin in curing infectious illnesses. Detailed studies are needed to determine the biologically effective compounds of $D$. miniatum and $X$. conspersa lichens.

\section{Conflict of Interest}

The authors declare that there is no conflict of interest. 


\section{References}

Aadesariya, M.K., Ram, V.R. and Dave, P.N., 2017. Evaluation of antioxidant activities by use of various extracts from Abutilon pannosum and Grewia tenax in the Kachchh Region. International Journal of Research in Engineering and Innovation, 1 (3), 97-112.

Arnao, M.B., Cano, A. and Acosta, M., 2001. The hydrophilic and lipophilic contribution to total antioxidant activity. Food Chemistry, 73, 239244.

Aslan, A., Güllüce, M., Sökmen, M., Adıgüzel, A., Şahin, F. and Özkan, H., 2006. Antioxidant and antimicrobial properties of the lichens Cladonia foliacea, Dermatocarpon miniatum, Evernia divaricata, Evernia prunastri and Neofuscalia pulla. Pharmaceutical Biology, 44 (4), 247-252.

Balasubramanian, M. and Nirmala, P. 2014a. Antimycobacterial activity of foliose lichens on plant and animal pathogens. International Journal of Pharmaceutical Sciences and Research, 5 (11), 4825-4831.

Balasubramanian, M. and Nirmala, P. 2014b. Evaluation of anti-oxidant properties of foliose lichens. Journal of Chemical and Pharmaceutical Research, 6 (9), 177-184.

Brand-Williams, W., Cuvelier, M.E. and Berset, C., 1995. Use of a free radical method to evaluate antioxidant acitivity. LWT - Food Science and Technology, 28, 25-30.

Buçukoğlu, T.Z., Albayrak, S., Halıcı, M.G. and Tay, T. 2013. Antimicrobial and antioxidant activities of extracts and lichen acids obtained from some Umbilicaria species from Central Anatolia, Turkey. Journal of Food Processing and Preservation, 37 (6), 1103-1110.

Crawford, S.D. 2015. Lichens used in traditional medicine In: Rankovic B (ed) Lichen secondary metabolites, Springer International Publishing, Switzerland, pp 27-80.

De Paz, G.A., Raggio, J., Gómez-Serranillos, M.P., Palomino, O.M., González-Burgos, E., Carretero, M.E. and Crespo, A. 2010. HPLC isolation of antioxidant constituents from Xanthoparmelia spp. Journal of Pharmaceutical and Biomedical Analysis, 53, 165-171.

Duman, D.C. 2009. Türkiye'de bazı liken türlerindeki usnik asitin HPLC yöntemi ile değerlendirilmesi ve antimikrobiyal aktiviteleri. Turk Hijyen ve Deneysel Biyoloji Dergisi, 66 (4), 153-160.

El Hajaji, H,, Lachkar, N., Alaoui, K., Cherrah, Y., Farah, A., Ennabili, A., Bali, B.E. and Lachkar, M. 2010. Antioxidant properties and total phenolic content of three varieties of Carob tree leaves from Morocco. Records of Natural Products, 4 (4), 193-204.

Gunasekaran, S., Rajan, V.P., Ramanathan, S., Murugaiyah, V., Samsudin, M.W. and Din, L.B. 2016. Antibacterial and antioxidant activity of lichens Usnea rubratincta, Ramalina dumeticola, Cladonia verticillata and their chemical constituents. Malaysian Journal of Analytical Sciences, 20 (1), 1-13.

Hossain, M.S., Uddin, M.S., Kabir, M.T., Begum, M.M., Koushal, P., Herrera-Calderon, O., Akter, R., Asaduzzaman, M. and Abdel-Daim, M.M. 2017 In vitro screening for phytochemicals and antioxidant activities of Syngonium podophyllum L.: An Incredible therapeutic plant. Biomedical and Pharmacology Journal, 10 (3), 1267-1277.

Jeon, H.S., Lökös, L., Han, K.S., Ryu, J.A., Kim, J.A., Koh, Y.J. and Hur, J.S. 2009. Isolation of lichen- forming fungi from Hungarian lichens and their antifungal activity against fungal pathogens of hot pepper anthracnose. The Plant Pathology Journal, 25 (1), 38-46.

Joshi, J. and Sahu, O. 2014. Azadirachta Indica leaves as antibacterial treatment on drinking water. International Journal of Clinical Nutrition, 2 (2), $36-40$.

Kumar, J., Dhar, P., Tayade, A.B., Gupta, D. , Chaurasia, O.P., Upreti, D.K., Arora, R. and Srivastava, R.B. 2014. Antioxidant capacities, phenolic profile and cytotoxic effects of saxicolous lichens from Trans-Himalayan cold desert of Ladakh. Plos One, 9 (6), 1-19.

Kumar, S., Dhankhar, S., Arya, V.P., Yadav, S. and Yadav, J.P. 2012. Antimicrobial activity of Salvadora oleoides Decne. against some microorganisms. Journal of Medicinal Plants Research, 6 (14), 2754-2760.

Laska, G. and Kiercul, S. 2014. Pharmacological activity of secondary metabolites isolated from Xanthoparmelia conspersa (Ehrh ex Ach.) Hale lichen. Planta Medica, 80-84.

Loizzo, M.R., Tundis, R., Bonesi, M., Menichini, F., Mastellone, V., Avallone, L. and Meninchini, F. 2012. Radical scavenging, antioxidant and metal chelating activities of Annola cherimola Mill. peel and pulp in relation to their total phenolic and total flavonoid contents. Journal of Food Composition and Analysis, 25, 179-184.

Mahesh, B. and Satish, S. 2008. Antimicrobial activity of some important medicinal plant against plant and human pathogens. World Journal of Agricultural Sciences, 4, 839-843. 
Manojlovic, N.T., Solujic, S. and Sukdolak, S. 2002. Antimicrobial activity of an extract and anthraquinones from Caloplaca schaereri. Lichenologist, 34 (1), 83-85.

Marijana, K., Branislav, R. and Slobodan, S. 2010. Antimicrobial activity of the lichen Lecanora frustulosa and Parmeliopsis hyperopta and their divaricatic acid and zeorin constituents. African Journal of Microbiology Research, 4 (9), 885890.

Millot, M., Girardot, M., Dutreix, L., Mambu, L. and Imbert, C. 2017. Antifungal and anti-biofilm activities of acetone lichen extracts against Candida albicans. Molecules, 22, 651-662.

Molnár, K. and Farkas, E. 2010. Current results on biological activities of lichen secondary metabolites: a review. Zeitschrift für Naturforschung C, 65, 157-173.

Murray, P.R., Baron, E.J., Pfaller, M.A., Tenovar, F.C. and Yolke, R.H. 1995. Manual of Clinical Microbiology. ASM Press, Washington DC, $2256 \mathrm{p}$.

NCCLS (National Committee for Clinical Laboratory Standards) (1993). Performanc standards for antimicrobial disk suscebility test, Approved Standard pp. 2-6.

Odabasoglu, F., Aslan, A., Cakir, M., Süleyman, H., Karagöz, Y., Bayır, Y. and Halici, M. 2005. Antioxidant activity, reducing power and total phenolic content of some lichen species. Fitoterapia, 76 (2), 216-219.

Paudel, B., Bhattarai, H.D., Pandey, D.P., Hur, J.S., Hong, S.G., Kim, I. C. and Yim, J.H. 2012. Antioxidant, antibacterial activity and brine shrimp toxicity test of some mountainous lichens from Nepal. Biological Research, 45 (4), 387-391.

Prieto, P., Pineda, M. and Aguiler, M. 1999. Spectrophotometric quantition of antioxidant capacity through the formation of a phosphomolybdenum complex: specific application to the determination of Vitamin E. Analytical Biochemistry, 269, 337-341.

Rani, R., Sharma, D., Chaturvedi, M. and Yadav, J.P. 2017. Antibacterial activity of twenty different endophytic fungi isolated from Calotropis procera and time kill assay. Clinical Microbiology, 6, 280-286.

Rankovic, B., Rankovic, D. and Maric, D. 2010. Antioxidant and antimicrobial activity of some lichen species. Microbiology, 79 (6), 809-815.

Rebaya, A., Belghith, S.I., Baghdikian, B., Leddet, V.M., Mabrouki, F., Olivier, E., Cherif, J.K. and
Ayadi, M.T. 2014 Total phenolic, total flavonoid, tannin content and antioxidant capacity of Halimium halimifolium (Cistaceae). Journal of Applied Pharmaceutical Science, 5 (1), 52-57.

Reddey, A.R.K. and Grace, J.R. 2016. In Vitro evaluation of antioxidant activity of methanolic extracts of selected mangrove plants. Medicinal and Aromatic Plants, 5 (3), 1-5.

Saenz, M.T., Garcia, M.D. and Rowe, J.G. 2006. Antimicrobial activity and phytochemical studies of some lichens from south of Spain. Fitoterapia, 77 (3), 156-159.

Šarić, L., Čabarkapa, I., Beljkaš, B., Mišan, A., Sakač, M.B. and Plavšić, D. 2009. Antimicrobial activity of plant extracts from Serbia. Food Processing Quality and Safety, 1 (2), 1-5.

Sharma, B.C. and Kalikotay, S. 2012. Screening of antioxidant activity of lichens Parmotrema reticulatum and Usnea sp. from Darjeeling hills, India. IOSR Journal of Pharmacy, 2 (6), 54-60.

Sharma, P., Sharma, P.C., Patil, S., Sen, R. and Kumar, A. 2012. In vitro evaluation of antibacterial activity of extract from Parmelia and Dermatocarpon spp. of lichen against the MDR clinical isolates of Staphylococcus aureus and Escherichia coli. Advances in Pharmacology and Toxicology, 13 (1), 15-21.

Sisodia, R., Geol, M., Verma, S., Rani, A. and Dureja, P. 2013. Antibacterial and antioxidant activity of lichen species Ramalina roesleri. Natural Product Researchs, 27 (23), 2235-2239.

Slinkard, K. and Singleton, V.L. 1977. Total phenol analysis: automation and comparison with manual methods. American Journal of Enology and Viticulture, 28, 49-55.

Smith, C.W., Aproot, A., Coppins, B.J., Fletcher, A., Gilbert, O.L., James, P.W. and Wolseley, P.A. 2009. The Lichens of Great Britain and Ireland. British Lichen Society, London, P. 1046 pp.

Sökmen, B.B., Kınalığlu, S. and Aydın, S. 2018. Evaluation of antifungal potentials and antioxidant capacities of some foliose lichen species. Süleyman Demirel University Journal of Natural and Applied Sciences, 22 (1), 148152.

Yumrutas, Ö. and Saygıdeger, S.D. 2012. Determination of antioxidant and antimutagenic activities of Phlomis armeniaca and Mentha pulegium. Journal of Applied Pharmaceutical Science, 2 (1), 36-40

Yücel, O., Odabaşoğlu, F., Güllüce, M., Çalık, Z.Z., Çakır, A., Aslan, A., Yazıcı, K. and Halıcı, M. 
2007. Antioxidant and antimicrobial properties of a lichen species, Cladonia rangiformis growing in Turkey. Turkish Journal of Pharmaceutical Science, 4 (2), 101-109.
Zhishen, J., Mengcheng, T. and Jianming, W. 1999. The determination of flavonoid contents in mulberry and their scavenging effects on superoxide radicals. Food Chemistry, 64, 555559. 